Working Paper 2008:12

Department of Economics

\title{
Intergovernmental Grants and Bureaucratic Power
}

Matz Dahlberg, Heléne Lundqvist and Eva Mörk 
Department of Economics

Working paper 2008:12

Uppsala University

October 2008

P.O. Box 513

ISSN $1653-6975$

SE-751 20 Uppsala

Sweden

Fax: $+{ }_{4} 6184711478$

Intergovernmental Grants and Bureaucratic Power

Matz Dahlberg, Heléne Lundqvist and Eva Mörk

Papers in the Working Paper Series are published on internet in PDF formats.

Download from http://www.nek.uu.se or from S-WoPEC http://swopec.hhs.se/uunewp/ 


\title{
Intergovernmental Grants and Bureaucratic Power ${ }^{*}$
}

\author{
by \\ Matz Dahlberg ${ }^{\dagger}$, Heléne Lundqvist ${ }^{\natural}$ and Eva Mörk ${ }^{\perp}$
}

October 20, 2008

In their role as agenda setters and implementers of political decisions, bureaucrats potentially have the power to influence decisions in their own favor. It is however difficult to empirically test whether bureaucrats actually are involved in such actions. In this paper we suggest and apply a new way of testing the hypothesis that bureaucrats can and do in fact affect policy to their own benefit. Making use of a discontinuity in the Swedish grant system, we estimate causal effects of intergovernmental grants on different types of personnel employed by the local governments. On the margin, we find a large, positive effect of grants on the number of bureaucrats in the central administration, but no effects on the number of personnel in other important sectors run by the local government (child care, schools and elderly care). These results support the view that bureaucrats are able to, and do indeed, affect the allocation of grants within municipalities to support own goals.

Keywords: Fiscal federalism, grants, bureaucrats, rent seeking, discontinuity analysis JEL-codes: C33, H11, H70, H83, J45

\footnotetext{
* We are grateful for comments from Jan Brueckner, Karin Edmark, Jon H Fiva, Ben Lockwood, seminar participants at Uppsala University, University of Barcelona, Government Institute for Economic Research (VATT) in Helsinki, and from participants at the conference on "New Perspectives on Fiscal Federalism" in Berlin in October 2007.

$\dagger$ Department of Economics, Uppsala University, PO Box 513, SE-751 20 Uppsala, Sweden; IFAU; CESifo

${ }^{a}$ Department of Economics, Uppsala University, , PO Box 513, SE-751 20 Uppsala, Sweden.

${ }^{\perp}$ Department of Economics, Uppsala University, PO Box 513, SE-751 20 Uppsala, Sweden; IFAU
} 


\section{Introduction}

Economic policy does not always turn out the way citizens desire. There are several reasons for this. For one thing, once in office politicians may have incentives to deviate from the promises that they made during the election campaign. Moreover, the decision of politicians are to be implemented by bureaucrats, i e civil servants in the central administration. These bureaucrats are often not only implementers but can potentially also impact politicians at the time of the actual decision-making. The purpose of this paper is to test whether they use this power to pursue own goals.

That bureaucrats play an important role in the public decision-making process has long been recognized by economists. ${ }^{1}$ In specific, there are two factors that give bureaucrats power over the decision-making process. First, bureaucrats are owners of information that other agents do not have access to. Second, the output produced by the public bureau is typically extremely hard to measure. In a world with uncertainty it is therefore close to impossible for any outside agent to monitor the performance of bureaucrats. From a voter's point of view this difficulty is problematic, because in the same way as we expect individuals to maximize own utility, we would expect bureaucrats to use their power in order to maximize their own utility, which is not necessarily the same as maximizing voters' utility. Of course, bureaucrats may also be motivated by other objectives, such as desires to create a good society, or to make the public decisionmaking as efficient as possible. Our view is that the issue of what motivates bureaucrats is yet to be convincingly settled.

For the same reason that it is hard to monitor the behavior of bureaucrats, theories of bureaucratic behavior are intrinsically hard to empirically test. In this paper we suggest

\footnotetext{
${ }^{1}$ Early contributions discussing the role of bureaucrats are Tullock (1965), Downs (1967), Niskanen (1971), and Romer and Rosenthal (1979). Later contributions include Moene (1986) that shows that deviations from the socially optimally bureau are likely. More recent authors argue that bureaucrats are driven by career concerns, see, e g, Dewatripont, Jewitt and Tirole (1999) and Alesina and Tabellini (2007). That bureaucrats matter for the political decision-making process as well as in the implementation phase has also been long recognized by the political science literature, see, e g, Peters (1995), Wilson (1989), and Lipsky (1980).
} 
and apply one way of testing whether bureaucrats act so as to pursue own goals. Our strategy involves estimating causal effects of general, non-matching intergovernmental grants on different types of personnel employed by the local governments, including personnel in the central administration (which we in this paper denote as bureaucrats). This can be done thanks to detailed panel data on the number of employees in different local governmental sectors in Sweden 1996-2004. The idea is that we expect selfinterested bureaucrats to desire to increase the number of fellow bureaucrats. ${ }^{2}$ There are several reasons as to why they should care about this; higher power against other groups, higher job security, lower work load etc. If bureaucrats pursue goals that are different from the electorate's we would thus expect to see an asymmetric pattern, where an increase in grants leads to an increase in the number of bureaucrats employed, but not necessarily a corresponding increase in the number of other types of personnel. ${ }^{3}$ Therefore, if we find that the effects of grants are larger on bureaucrats than on personnel in other sectors, we interpret this as an indication that bureaucrats have an independent say in the decision on what to do with additional general grants, and that they use this power to increase own utility.

The literature contains rather numerous studies that try to test the hypothesis that bureaucrats affect policy in their own interest. Several studies have compared costs between publicly and privately produced services, arguing that evidence indicating higher costs among public providers would support the view of bureaucrats as budget maximizers (for a list of studies along these lines, see Table 14.1 in Mueller, 1989). However, these comparisons hinge on the assumption that the quality of the output supplied by public and private suppliers is the same, which is questionable. Another way of testing whether bureaucratic power matters is to test different models against

\footnotetext{
${ }^{2}$ An alternative variable that the bureaucrats may want to affect is their own wages. However, given the Swedish setting with wage negotiations at the central level and only limited possibilities to set wages at the local level we believe that it is much easier for the bureaucrats to affect municipal labor demand than municipal wages. Also, it is potentially easier for the bureaucrats to argue that there is a need for more personnel rather than that there is a need for higher wages (or other materialistic things such as larger offices, for that matter).

${ }^{3}$ The line of reasoning applied in this paper, i e to indirectly look for patterns suggesting some sort of self-interested behavior, cheating, corruption or embezzlement when such activities are difficult to spot directly, has been used by others, e g, Card and Moretti (2007) who look for strategic behavior among U S politicians, Jacob and Levitt (2003)
} 
each other, one where bureaucrats matter and one where they do not. This is, for example, done by Romer and Rosenthal (1982), Filimon et al. (1982) and Romer et al. (1992), who take as starting point the asymmetric information model in Romer and Rosenthal (1979). In this model, it is assumed that bureaucrats have more information about grants received than voters have, which leads to spending levels higher than those desired by the voters. Romer and Rosenthal (1982) find that school budgets in Oregon that are 16.5 up to 43.6 percent higher than the budget preferred by the median voter pass referenda. Such large departures from the median voter's bliss point can pass since the bureaucrats are able to give a take-it-or-leave-it proposal to the voters in the referenda. Filimon et al. (1982) develop the fiscal illusion model even further by explicitly modeling voters' and bureaucrats' (agenda-setters') perceptions of intergovernmental grants; while a voter might misperceive the actual grant level, an agenda-setter is always assumed to have full knowledge of it. When testing the model, using the same data as in Romer and Rosenthal (1982), Filimon et al. find that voters seem to be very poorly informed about grants received by the school district. As a consequence, school spending in Oregon is too high. Romer et al. (1992) use data from New York school districts and link spending proposals to referendum outcomes. They find strong indications of budget maximization, especially in large districts. Other authors who test competing models of decision-making against each other are Shapiro and Sonstelie (1982) and Brueckner and O’Brien (1989). Shapiro and Sonstelie (1982) compare expenditures on general government, police, fire, and parks before and after the passing of Proposition 13 in 1978. Depending on whether the median voter or a budget-maximizing bureaucrat had the decision-making power, the responses to the Proposition, which limited property tax amendments in California, would be different. Shapiro and Sonstelie find expenditure responses consistent with powerful bureaucrats. Brueckner and O'Brien (1989) test two models of wage bargaining, one where bureaucrats act in the interest of their constituents and one where bureaucrats act in their

who look for cheating among teachers and school administrations, and Duggan and Levitt (2002) who look for corruption among Japan's elite sumo wrestlers. 
own interest. As opposed to earlier studies, they do not find any evidence in favor of the first model, i e no indications that bureaucrats try to maximize budgets. ${ }^{4}$

The test suggested by us involves estimating causal effects of grants on personnel employed by the municipality. This is not straightforward since it is likely that grants are endogenous; see Besley and Case (2000) for a general discussion of endogenous policies, and Knight (2002), Gordon (2004), and Dahlberg et al. (forthcoming) for a discussion of potential endogeneity of grants. In this paper, we will adopt a version of the identification strategy used by Dahlberg et al. (forthcoming). The idea is to make use of a discontinuity in the Swedish grant system where municipalities with a net outmigration above two percent receive grants whereas municipalities with a net outmigration below two percent do not. Since any direct effect of out-migration on personnel can be assumed to be smooth, the discontinuous variation that remains after controlling for the direct effects can be viewed as more or less random differences in the amount of grants received. Technically this exogenous variation is isolated by using the formula for the distribution of out-migration funds as an exclusion restriction in an IVestimation. The same type of identifying strategy has earlier been used by Guryan (2003) in a paper examining the effect of school resources on student achievement. ${ }^{5}$

On the margin, we find a large, positive effect of grants on the number of bureaucrats in the central administration employed by local governments, but no effects on the number of personnel in any of the other three important sectors run by the local government (child care, schools and elderly care). The asymmetries in these results can be taken as evidence of bureaucratic influence over the allocation of grants within municipalities - a conclusion that is strengthened by a detailed examination indicating that the instrument we employ in this paper is valid. When separating between the lower and the upper part of the distribution of influential bureaucrats, we find that the increase in the number of

\footnotetext{
${ }^{4}$ Other studies trying to identify bureaucrats as budget maximizers are Ott (1980), McGuire (1981), Kalseth and Rattsø (1997), and Dahlberg and Mörk (2006).

${ }^{5}$ A grant non-linearity could potentially be analyzed with the regression-discontinuity method (see, e g, Angrist and Lavy, 1999; Hahn et al., 2001; Lee, 2008). The grant formula used in this paper differs however from a classical
} 
bureaucrats consists of administrative personnel rather than high officials. We can think of several reasons for why high officials would use their power to employ more administrative personnel. First, a large staff of administrators will be able to cover a variety of tasks that would otherwise be assigned to someone further up the ladder. Hence, by employing more administrative personnel, the high officials can reduce their own work load. Second, having a large staff of administrators also increases the number that the higher officials are bosses over, which gives them more power. Finally, the scope for new appointments among high officials is likely to be rather restricted in municipalities of given size.

The outline of the rest of the paper is as follows: Section 2 presents the strategy used to identify the causal effects of intergovernmental grants on bureaucrats and other types of local government personnel. Section 3 gives some facts about the Swedish system and discusses the role played by bureaucrats in Sweden. Section 4 presents the data, whereas section 5 gives the baseline results. Thereafter, a detailed examination of the validity of the instrument is given in section 6. Section 7 examines which type of bureaucrats that is employed as grants increase and, finally, section 8 offers concluding remarks.

\section{Identification strategy}

We are interested in the causal effect of intergovernmental grants on different types of municipal personnel, $\mathrm{i}$ e the relationship we want to identify is given by

$$
y_{i, t}=\alpha_{0}+\alpha_{1} g_{i, t}+\varepsilon_{i, t},
$$

where $y_{i, t}$ is the number of personnel employed by municipality $i$ in year $t$ in either administration, child care, schools, or elderly care, and $g_{i, t}$ is grants received by the municipality. A (naïve) OLS-estimate of $\alpha_{1}$ will most likely be biased. The bias could be due to, e g, omitted variables and/or simultaneity of grants and personnel. Ideally, to

regression discontinuity design in two respects. First, all treated do not receive the same amount and, second, there is no "jump" in treatment at the cut-off point. 
eliminate the bias we would like to conduct an experiment were municipalities randomly are given different amounts of grants and then study their behavior. Since such an experiment does not exist (it seems quite politically infeasible) we turn to institutional details that allow us to come as close as possible to randomization of grants. Following Dahlberg et al. (forthcoming), we will use a discontinuity in the Swedish cost-equalizing grant formula as a source of exogenous variation. The costequalizing grants come with no strings attached (that is, municipalities can use the money in whatever way they prefer), and are intended to support municipalities that are characterized by demographic and other structural conditions associated with higher costs. We will return to the role played by these grants in sections 3 and 4 .

The component we use supports municipalities with a diminishing population and is allocated as follows: grants are distributed only to local governments with a net outmigration larger than two percent the last ten years (with a two-year lag). More formally, municipality $i$ receives out-migration grants in year $t\left(g_{i, t}^{m}\right)$ according to the following rule:

(2) $g_{i, t}^{m}\left\{\begin{array}{l}>0 \text { if } m_{(i, t-2)-(i, t-12)}>2 \\ =0 \text { if } m_{(i, t-2)-(i, t-12)} \leq 2\end{array}\right.$

where $m_{(i, t)-(i, t-j)}$ is the net out-migration rate in municipality $i$ between year $t$ and year $t-j$ whose size determines whether or not the municipality is treated with additional grants. Hence, in what follows $m_{(i, t)-(i, t-j)}$ will be referred to as the "treatmentdetermining covariate". For those eligible for the out-migration grant the amount received is proportional to the out-migration rate.

Figure 1 plots grants received by the municipalities against the rule. As can be seen from the figure, there is a well-defined cut-off at two percent where municipalities with lower net out-migration than two percent do not receive any grants whereas 
municipalities with net out-migration above two percent do receive grants. ${ }^{6}$ Thus, there is a discontinuity in the relationship between grants and out-migration.

Figure 1 Out-migration grants (SEK/capita) against net out-migration.

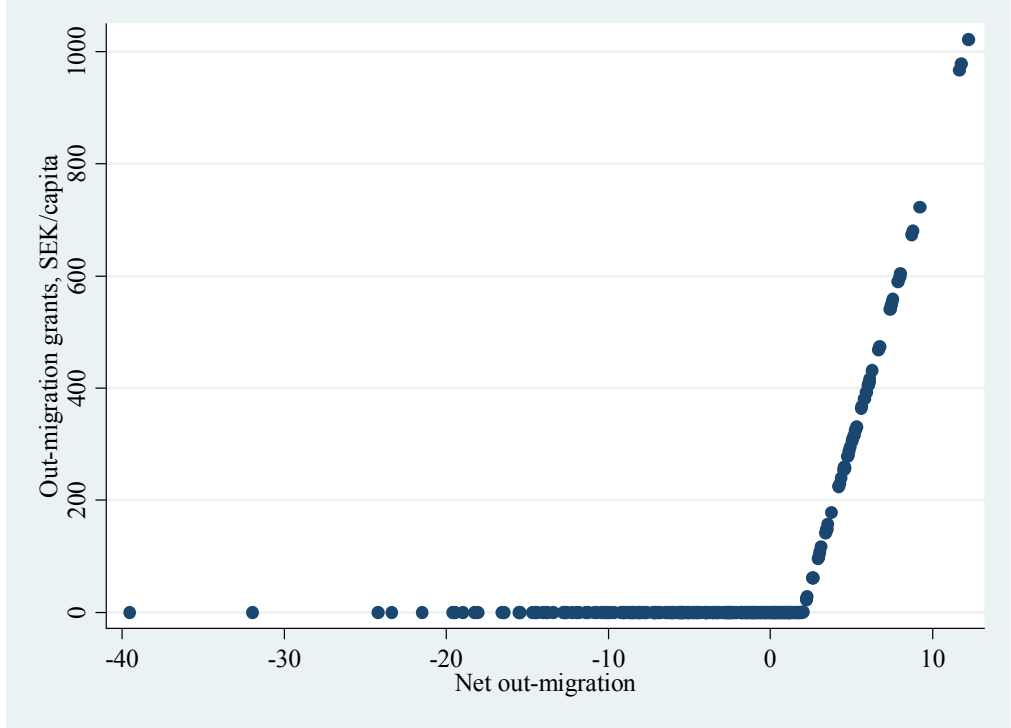

Let the discontinuity in equation (2) be denoted by $\Omega\left(m_{(i, t-2)-(i, t-12)}\right)$, where, again, $m_{(i, t-2)-(i, t-12)}$ is the treatment-determining covariate. In order to get an unbiased estimate of $\alpha_{1}$ in equation (1) we use this discontinuity as an instrument for $g_{i, t}$ in a two-stage procedure. However, since it is possible (and likely) that the treatment-determining covariate also partly determines the outcome of interest (i e municipal personnel) directly, we need to control for this variable in the estimations. If not, the instrument will be invalid. Since we do not know the exact form of this direct effect we allow for an as flexible functional form as possible. This implies that the first stage in the twostage least squares (2SLS) procedure is given by

$$
g_{i, t}=\gamma_{0}+\gamma_{1} \Omega\left(m_{(i, t-2)-(i, t-12)}\right)+f\left(\mathbf{m}_{(i, t-2)-(i, t-12)} ; \phi\right)+\eta_{i, t}
$$

\footnotetext{
${ }^{6}$ The total cost for this grant component is divided equally (per capita) between all municipalities, implying that it is neutral in terms of the federal budget.
} 
where $f(\cdot)$ is a smooth function of the treatment-determining covariate (net outmigration $)^{7}$, and that the second step (where the relationship of main interest is estimated) consequently is given by

$$
y_{i, t}=\alpha_{0}+\alpha_{1} \hat{g}_{i, t}+f\left(\mathbf{m}_{(i, t-2)-(i, t-12)} ; \boldsymbol{\delta}\right)+\varepsilon_{i, t},
$$

where $\hat{g}$ is predicted grants obtained from the estimation of equation (3).

Thanks to the discontinuity in the grant formula we are thus able to mimic an experimental setting quite closely. In terms of Figure 1, after controlling for the smooth direct effects of out-migration on personnel, municipalities on opposite sides of the kink are similar in all respects except that one is eligible for the grant and one is not. Any differences in personnel can therefore be attributed to essentially random differences in the amount of grants received. More formally, the exclusion restriction that is required for the instrument to be valid is that the functional form of the direct relationship between $y$ and the treatment-determining covariate (as given by the smooth functions in lagged net out-migration) is not the same as the functional form of the relationship between the treatment-determining covariate and grants (as described by the discontinuous out-migration grant formula, i e the selection mechanism). It is worth noting that since our suggested procedure estimates a direct causal effect omitted variable bias is no longer a concern, and for identification purposes there is no need to control for additional covariates or municipality fixed effects. ${ }^{8}$ We will however include year fixed effects to control for any aggregate shocks such as, e g, inflation that affects all jurisdictions in the same way.

In order for the estimated coefficient to represent a causal effect, the instrument needs to be valid (i e relevant and exogenous). The relevance of the excluded instrument can be examined by looking at the $t$-statistic and its associated $p$-value for the parameter on the

\footnotetext{
${ }^{7}$ In the estimations, we use up to a fourth-order polynomial in $m$ in the smooth function $f(\cdot)$.

${ }^{8}$ The assumption that no additional covariates are needed will be examined when checking the exogeneity of the instrument. See section 6 for more details.
} 
excluded variable in the first-stage estimation. How to test for exogeneity of the instrument is not obvious. What we will do is to use three different approaches to examine the exogeneity of the instrument. This will be further discussed in section 6 .

\section{Institutional background}

\subsection{Local governments in Sweden}

Decentralized governments in Sweden are among the largest in the world, with a comprehensive range of responsibilities, for example primary education, child care and care for the elderly. The provision of these services is very labor intense and roughly 20 percent of the entire work force is employed by the municipalities, making them the largest employer in the country. As a consequence, costs for personnel make up more than half of municipal expenditures. The most important source of municipal revenue is a proportional local income tax which makes up 60-70 percent of total revenues. The rest is made up of fees and grants. Since equalization is a major feature of the grant system, the importance of grants as a source of revenue varies substantially over jurisdictions, and the average figure is just above 15 percent. But there are also three of the municipalities in the region of Stockholm that actually were net contributors to the system during the entire 1996-2004 period.

A major grant reform in 1993 replaced a system of targeted central government grants to all municipal services (education, child and elderly care, social services and infrastructure) by a general lump-sum grant. This meant that the majority of grants were no longer ear-marked. After some early changes the new system that came into place in 1996 consisted of income-equalizating grants, cost-equalizing grants and a general per capita grant, all distributed as general lump-sum grants. The cost equalization aimed at reducing differences in structural cost conditions across municipalities, whereas the purpose of income equalization was to bring per capita tax revenues close to the 
national average. ${ }^{9}$ It is worth noting that the same grant system prevailed during the entire period studied in this paper.

\subsection{Do bureaucrats have any political power?}

The Swedish constitution establishes that "all public power in Sweden proceeds from the people", and that one of the means to the realization of this is independent local governments. ${ }^{10}$ However, it is not explicitly spelled out what is exactly meant by "independent local governments". Formally, decisions in the local governments are taken by the political majority in the municipal council. In reality, however, far from all questions are under the influence of the politicians. Like in politics in general, a lot of issues are so complex or require so many detailed decisions that it is better to leave the preparation and/or implementation to local officials. This means that a great portion of the actual power potentially lies in the hands of the bureaucracy. In Sweden this is even more likely on the local than on the central level, since the vast majority of the seats in the municipal council are held by unpaid leisure politicians, who also have full-time occupations. $^{11}$

The way that one has thought about the role of politicians on the one hand and that of bureaucrats on the other has varied over time in Sweden. ${ }^{12}$ For a long period it was considered best that all decisions were made by politicians and that the bureaucracy was a pure implementing institution. As the number and complexity of the decisions that had to be made grew, the old system got increasingly difficult to maintain. In the 1980's, when economic problems began to pile up in many municipalities, it was argued that things would run more efficiently if more power were put in the hands of local officials. The idea was that politicians were to decide what to do, while the bureaucrats decided how to do it. In practice it is however often more or less impossible to draw the line between the two. In a survey of local politicians, 30 percent thought that the division of

\footnotetext{
${ }^{9}$ Both of the equalizing grants are self-financed by equal per capita contributions from all municipalities.

${ }^{10}$ See the Instrument of Government, chapter 1, article 1.

${ }^{11}$ Of the 39,000 local politicians in Sweden, only 526 are full-time politicians. Over $97 \%$ of the local politicians work less than $40 \%$ of a full-time position as politicians. Over $81 \%$ of the municipalities have a maximum of two full-time politicians. Given the size and importance of the municipalities in Sweden, it goes without saying that the local bureaucrats have an important role to fill.
} 
responsibilities between politicians and bureaucrats is unclear and more than 50 percent felt that the role as a politician simply was to approve proposals made by officials (SKL, 2005). Although the views that were expressed in this survey may not be representative of the entire country ${ }^{13}$, the lack of power that these politicians experienced lend support to the argument that bureaucrats have power in the local decision-making process.

\section{Data}

In this paper we use a panel of 279 municipalities observed over the time period 19962004. ${ }^{14}$ As mentioned in section 2 , the grant formula that is used for identification is an element of the cost-equalizing grants designed to compensate local governments for additional costs due to large out-migration. During the period 1996-2004, the average out-migration grant as a fraction of total cost-equalizing grants for eligible municipalities amounts to around 18 percent, whereas the cost-equalizing grants for eligible municipalities amount to around 20 percent of total grants. As described previously, jurisdictions with net out-migration below two percent do not receive any out-migration grant whereas those above two percent do. Over the studied period, 112 municipalities never received any out-migration grants, 55 municipalities received grants all nine years and the remaining 112 municipalities received grants some, but not all years. As can be seen from the map in Figure 2, the receiving municipalities are all over the country, even though they are concentrated in the north of Sweden.

\footnotetext{
${ }^{12}$ For a discussion on this, see, e g, Montin (2002).

${ }^{13}$ The survey was voluntary and only 17 municipalities took part in it. 2,204 out of 3,188 recipients responded, i e a response rate of 69 percent. The entire survey is published in SKL (2005).

${ }_{14}$ The dataset covers all municipalities except for eight that were affected by consolidations (Bollebygd, Borås, Lekeberg, Örebro, Nykvarn, Södertälje, Knivsta and Uppsala) and three that have responsibilities that the other municipalities do not have (Gotland, Malmö and Göteborg).
} 
Figure 2 Distribution of out-migration grants over the period 1996-2004.

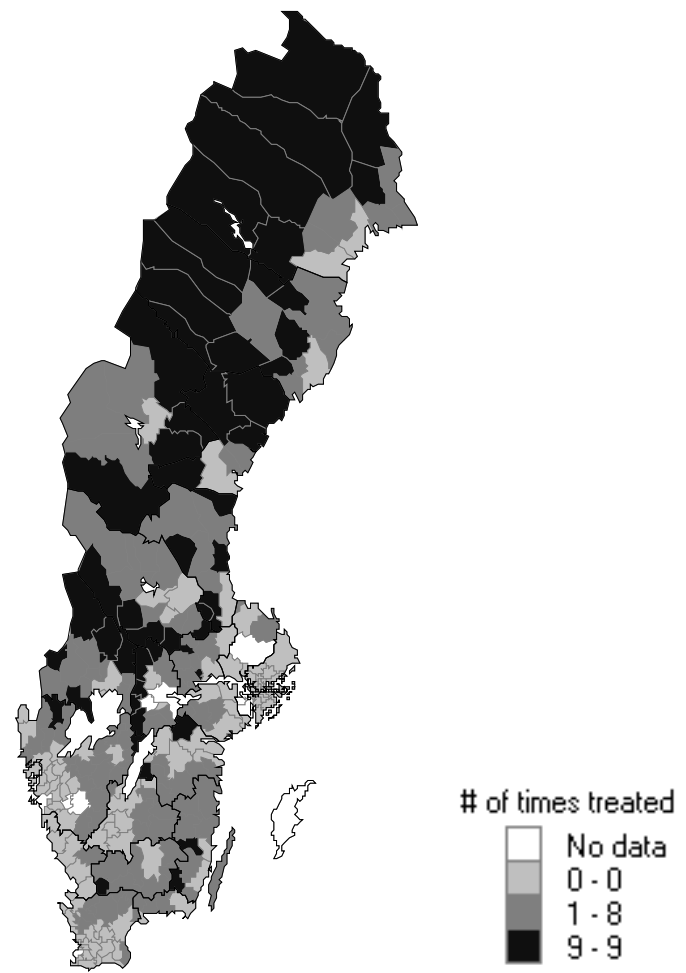

Table 1 gives summary statistics for the two grants variables (cost-equalizing grants and migration grants, both measured per capita), the dependent variables (personnel in the central administration (i e bureaucrats) ${ }^{15}$ and personnel in child care, schools, and elderly care, measured in full-time equivalents per 1,000 capita) and the treatmentdetermining covariate (net out-migration). ${ }^{16}$ The motivation for choosing to compare the results for the bureaucrats with personnel in child care, schools, and elderly care is that these three sectors are the largest and have traditionally been the most important ones. The large standard deviations relative to the means and the negative minimum values of cost-equalizing and migration grants reflect the fact that the grant system is self-

\footnotetext{
${ }^{15}$ Note that the categorization into different types of personnel used throughout the paper is such that the entire staff of bureaucrats works in the municipal administration office and does not include, for example, the superintendent of a school (who is categorized as school personnel).

${ }^{16}$ It is worth noting that the net out-migration rate that determines whether or not a municipality is eligible is taken from register data. There is hence no room for the municipality to manipulate the figures in order to become eligible for the grants.
} 
financed. As for personnel, most people are employed in elderly care and schools -21 and 17 full-time equivalents per 1,000 inhabitants, respectively.

Table 1 Summary statistics for the variables used in the empirical analysis.

\begin{tabular}{lllll}
\hline Variable & Mean & St dev & Min & Max \\
\hline Personnel, central administration & 5.48 & 1.13 & 2.19 & 12.86 \\
Personnel, child care & 10.55 & 1.72 & 3.33 & 17.90 \\
Personnel, schools & 16.71 & 2.71 & 8.45 & 32.09 \\
Personnel, elderly care & 21.20 & 6.66 & 1.48 & 41.11 \\
Cost-equalizing grants & 532.1 & 2,452 & $-3,471$ & 13,196 \\
Migration grants & 111.7 & 286.8 & -125.5 & 1,384 \\
Net out-migration & -0.789 & 7.92 & -42.95 & 16.64 \\
Wages, bureaucratic personnel & 20,039 & 2,353 & 15,094 & 28,657 \\
Wages, personnel in child care & 15,995 & 1,708 & 12,458 & 20,514 \\
Wages, personnel in schools & 20,055 & 1,937 & 16,075 & 25,092 \\
Wages, personnel in elderly care & 15,608 & 1,545 & 12,621 & 20,965 \\
Share of population 0-6 & 0.079 & 0.013 & 0.047 & 0.128 \\
Share of population 7-15 & 0.122 & 0.012 & 0.068 & 0.164 \\
Share of population 80+ & 0.054 & 0.014 & 0.012 & 0.091 \\
Population & 27,229 & 48,884 & 2,575 & 761,721 \\
Tax base & 105,957 & 19,219 & 69,399 & 256,754 \\
Share foreign born & 0.040 & 0.027 & 0.006 & 0.291 \\
\hline \# of observations & & & 2,511 & \\
\hline
\end{tabular}

Notes: Grants and tax base are defined in SEK per capita. Personnel are defined as number of full-time equivalents per 1,000 inhabitants and wages are defined as the average monthly salary of a full-time equivalent. Net out-migration is given in percent. Data is obtained from Statistics Sweden and from The Swedish Association of Local Authorities and Regions.

Table 1 also presents the socio-economic variables that will be used in an approach to test the exogeneity of the instrument (see section 6.2). These variables are wages paid to municipal employees, share of population aged $0-6$, share of population aged 7-15, share of population aged 80 years or older, population size, the per capita tax base, and the share of foreign-born citizens. There are large variations across municipalities in 
these variables as well as in the amount of migration (which of course is the underlying reason why there is a need for equalization).

\section{The effects of grants on municipal personnel in different sectors}

In this section we will present the two-stage least squares (2SLS) estimates of the model presented in equations (3) and (4) to examine whether grants, on the margin, have a different impact on the number of bureaucrats than on other types of personnel. In order to test whether the instrument is relevant, we first present the results from the first stage. Thereafter, we turn to the estimates of the causal effects from the second stage.

\subsection{First-stage estimates}

Since there might exist direct effects of the treatment-determining covariate on personnel, we need to control for a flexible function of this covariate in order for the instrument to be valid. One might worry that when doing this, there will be no explanatory power left in the instrument, which thereby will fail to be relevant. Whether this is the case or not will be clear from the first-stage estimates, more precisely from the $\mathrm{p}$-values of the estimate of the partial correlation between the formula for the outmigration grant $\left(\Omega\left(m_{(i, t-2)-(i, t-12)}\right)\right)$ and total cost-equalizing grant $\left(g_{i, t}\right)$. This estimate corresponds to $\gamma_{1}$ in the first-stage regression given in equation (3). If $\gamma_{1}$ is statistically significant we know that after controlling for the direct effects of the smooth function in net out-migration, the out-migration grant still has an impact on total cost-equalizing grant, implying that our instrument is relevant.

Since we do not know the form of the direct effects of the treatment-determining covariate we wish to be as flexible as possible. Therefore, we use up to a $4^{\text {th }}$ order polynomial in net out-migration. Table 2 shows the first-stage estimates and associated standard errors of $\gamma_{1}$ in equation (3). The standard errors are robust to arbitrary residual 
heteroskedasticity and serial correlation within municipality. ${ }^{17}$ Each row corresponds to estimation with a $2^{\text {nd }}, 3^{\text {rd }}$ or $4^{\text {th }}$ order polynomial in $f(\cdot)$.

Table 2 First-stage estimates.

\begin{tabular}{ll}
\hline Dependent variable: & Cost-equalizing grants \\
\hline $2^{\text {nd }}$ order polynomial & $3.251^{* * *}$ \\
& $(0.778)$ \\
$3^{\text {rd }}$ order polynomial & $3.697^{* * *}$ \\
& $(1.134)$ \\
$4^{\text {th }}$ order polynomial & $4.866^{* * *}$ \\
& $(1.443)$ \\
\hline \# of observations & 2,511 \\
\hline
\end{tabular}

Notes: The table presents estimates of $\gamma_{1}$ in the first-stage equation (3). Robust standard errors adjusted for within cross-sectional serial correlation in parentheses. $* * *$ denotes significance at the 1 percent level. Time dummies and smooth functions with out-migration in $2^{\text {nd }}-4^{\text {th }}$ order polynomial are included in the estimations.

From the table it is clear that all estimates are highly significant in a statistical sense. We can also note that the economic significance (the magnitude of the point estimate) is increasing over the order of polynomials in the smooth function. If anything, the instrument hence gets stronger the more flexible the control function is. The overall conclusion is that the instrument works well in the sense that it is relevant. Next we turn to the two-stage least square estimates of the causal effect of grants on municipal personnel.

\subsection{Two-stage least squares estimates}

Table 3 presents the 2SLS estimates of $\alpha_{1}$ from equation (4) for four different types of municipal personnel: bureaucrats, personnel in child care, personnel in schools, and personnel in elderly care. Again, each row corresponds to estimation with a $2^{\text {nd }}, 3^{\text {rd }}$, or $4^{\text {th }}$ order polynomial in $f(\cdot)$. Since the measurement units of the dependent variable (personnel per 1,000 capita) and the variable of interest (total cost-equalizing grants per

\footnotetext{
${ }^{17}$ Rigidities in hiring and firing suggest that there is a time-lag in employment, which is also shown to be the case in Bergström et al. (2004). This emphasizes the importance of adjusting the standard errors accordingly. This is done
} 
capita) are very different, the variables are rescaled to have a zero mean and a standard deviation of one in order to facilitate the interpretation of the estimated parameters.

To start with the results for bureaucrats, it is clear from the first column in Table 3 that grants have a positive and statistically significant effect on the number of bureaucrats employed by the municipality. Since the point estimate is somewhat affected when going from a $2^{\text {nd }}$ to a $3^{\text {rd }}$ order polynomial in the treatment-determining covariate (increasing from 0.62 to 0.87 ), but is mainly unaffected when going from a $3^{\text {rd }}$ to a $4^{\text {th }}$ order polynomial, this is an indication that a $3^{\text {rd }}$ order polynomial in the treatmentdetermining covariate is flexible enough to control for the direct effect of out-migration on the number of bureaucrats. The estimates for the two highest-order polynomials are around 0.85 . The interpretation of this figure is that a one standard deviation increase in grants leads to a 0.85 standard deviation increase in bureaucrats per capita, which must be considered an economically significant effect. Without the rescaling the analogous effect is that a 100 SEK per capita increase in grants leads to an increase of 0.03 fulltime equivalent bureaucrats per 1,000 capita, which is around 0.5 percent of the mean. Again, this is a substantial effect considering that the mean of the absolute value of the cost-equalizing grants is around 1,500, implying that 100 SEK constitute a 6-7 percent increase. $^{18}$

According to Dahlberg et al. (forthcoming) increased intergovernmental grants lead to increased municipal spending Krona for Krona. The effects we see for bureaucrats might therefore not be that extraordinary - the money has to go somewhere, and since the services municipalities supply are labor intense we would expect to see increases in the number of personnel. Consequently, we would also expect to find similar effects in the other sectors of the municipal labor market. If, however, the effects on other types of personnel are unambiguously smaller than the effects on bureaucratic personnel, our result is an indication that bureaucrats use their power in the local decision-making using the cluster command in STATA. 
process to their own advantage by allocating a larger share of additional grants to themselves. We therefore proceed by looking for similar effects in three of the most important sectors in local public employment, namely child care, schools, and elderly care.

The resulting 2SLS estimates of $\alpha_{1}$ are presented in the last three columns of Table 3. The results are quite striking - none of the estimates are statistically significant. This is not due to larger standard errors but to smaller point estimates. It thus seems like the number of personnel in child care, schools, and elderly care are unaffected by a marginal increase in grants to the municipality.

Table 3 Effects of grants on bureaucrats and personnel in child care, schools and elderly care. 2SLS estimates.

\begin{tabular}{lllll}
\hline Dependent variable: & Bureaucrats & $\begin{array}{l}\text { Personnel in } \\
\text { child care }\end{array}$ & $\begin{array}{l}\text { Personnel in } \\
\text { schools }\end{array}$ & $\begin{array}{l}\text { Personnel in } \\
\text { elderly care }\end{array}$ \\
\hline $2^{\text {nd }}$ order polynomial & $0.620^{* * *}$ & -0.010 & -0.355 & -0.380 \\
& $(0.199)$ & $(0.183)$ & $(0.255)$ & $(0.233)$ \\
$3^{\text {rd }}$ order polynomial & $0.869^{* * *}$ & -0.061 & -0.506 & -0.387 \\
& $(0.300)$ & $(0.345)$ & $(0.382)$ & $(0.322)$ \\
$4^{\text {th }}$ order polynomial & $0.837 * * *$ & 0.008 & -0.318 & -0.190 \\
& $(0.296)$ & $(0.243)$ & $(0.285)$ & $(0.274)$ \\
\hline \# of observations & 2,511 & 2,511 & 2,511 & 2,511 \\
\hline
\end{tabular}

Notes: The four columns report standardized estimates of $\alpha_{1}$ in the second-stage equation (4) with dependent variable bureaucrats, child care, elderly care and school personnel, respectively. Robust standard errors adjusted for within cross-sectional serial correlation in parentheses $* * *, * *$ and * denotes significance at the 1,5 and 10 percent level. Time dummies and smooth functions with out-migration in $2^{\text {nd }}-4^{\text {th }}$ order polynomial are included in the estimations.

Let us summarize the results in Table 3 . We have found that, on the margin, grants increase the number of bureaucrats in the central administration, but do not have any effects on other types of personnel. The conclusion is that the effects we see on bureaucrats are in line with the hypothesis that they have an independent say in the decision on what to do with additional grants, and that they use this power to increase

\footnotetext{
${ }^{18}$ Because of the equalizing feature of the grants more than half of the observations on cost-equalizing grants are negative. This implies that evaluating the size of a grant increase in the context of the mean value from Table 1 would be misleading.
} 
the number of fellow bureaucrats. By employing more people in the central administration they are likely to be better off in the sense that their own workload decreases. Also, the size of the bureau is increased. Of course, it could also be that the politicians wish to employ more bureaucrats to decrease their workload, or that the bureaucrats believe that it is also in the interest of the voters to have many bureaucrats. These interpretations do however seem less likely given, for example the survey evidence discussed above saying that more than half of the politicians that answered the survey felt that their role as a politician simply was to approve proposals made by officials (see SKL, 2005). Another potential explanation could be that the grants themselves increase the need for an administration handling the distribution of these grants. However, we believe this to be quite far-fetched, given that the grants arrive with no strings attached and that there is no application procedure in place.

The conclusion drawn above hinges crucially on the validity of the instrument. From the first-stage estimates presented earlier, we saw evidence of instrument relevance. But does the instrument really provide an exogenous variation? We will in the next section examine in depth whether the assumption of exogeneity is fulfilled.

\section{Is the instrument valid?}

For the instrument to be valid it needs to be both relevant and exogenous. The firststage estimates in section 5.1 show that the instrument is indeed relevant. To examine whether our instrument also provides an exogenous variation, we will use three different approaches; (i) a graphical analysis to examine, visually, if the smooth function $f(\cdot)$ that should control for any direct effects of out-migration is doing its job, (ii) adding additional covariates to our baseline specification to see how sensitive the estimates are to this (the point estimates should not be much affected if the instrument is truly exogenous), and (iii) using an additional discontinuous rule to test, by means of the Hansen $J$ test, the model specification/instrument validity by utilizing the overidentifying restriction. 


\subsection{Graphical analysis}

Our identifying assumption is that, once we have controlled for smooth functions of the treatment-determining covariate, we have controlled for all direct effects of this covariate on the outcome. Any remaining relationship between the outcome variable and the net out-migration variable should then come from the grant formula, implying that there should not be any correlation between the two variables for net out-migration rates below two percent (if anything, there should only be a relationship between the two variables for a net out-migration rate of two percent or more). To examine whether this is indeed the case we estimate the second step equation (4), but leave out the predicted grants variable. We thereafter plot the residuals from that equation against net out-migration. What we would like to see then is a zero relationship between the two variables for those municipalities that have not been treated (i e, those municipalities with a net out-migration rate below two percent). As a comparison, we also do this without controlling for any direct effects in order to see the raw correlations between the net out-migration rate and the outcome variable (deviations from mean).

Figure 3 shows the predicted residuals from the following two regressions

$$
\begin{aligned}
& y_{i, t}=\alpha_{0}+\varepsilon_{i, t} \\
& y_{i, t}=\alpha_{0}+f\left(\mathbf{m}_{(i, t-2)-(i, t-12)} ; \boldsymbol{\delta}\right)+\varepsilon_{i, t},
\end{aligned}
$$

where $y$ is municipal personnel and $f(\cdot)$ is a $4^{\text {th }}$ order polynomial in the historic outmigration rate. ${ }^{19} \mathrm{We}$ see from the figure that there seems to exist a relationship between municipal personnel and net out-migration when we do not control for the treatmentdetermining covariate (using the residuals from equation (5)), but that the relationship more or less disappears for those municipalities that have not been treated when controlling for a $4^{\text {th }}$ order polynomial in net out-migration (using the residuals from

\footnotetext{
${ }^{19}$ In the figures we show the relationship between the two variables for those municipalities with a net out-migration rate larger than -20 percent and lower than 10 percent. This constitutes the mass of the observations. The reason for excluding some municipalities with extreme out-migration rates is that they are so few and that the locally weighted regressions used in constructing the estimates in the figures are sensitive to the number of observations within the bandwidth.
} 
equation (6)). We interpret this as evidence that our control function is flexible enough to control for any direct effects of net out-migration on municipal personnel, validating our instrument. 
Figure 3 Estimated residuals from equations (5) and (6) against net out-migration.
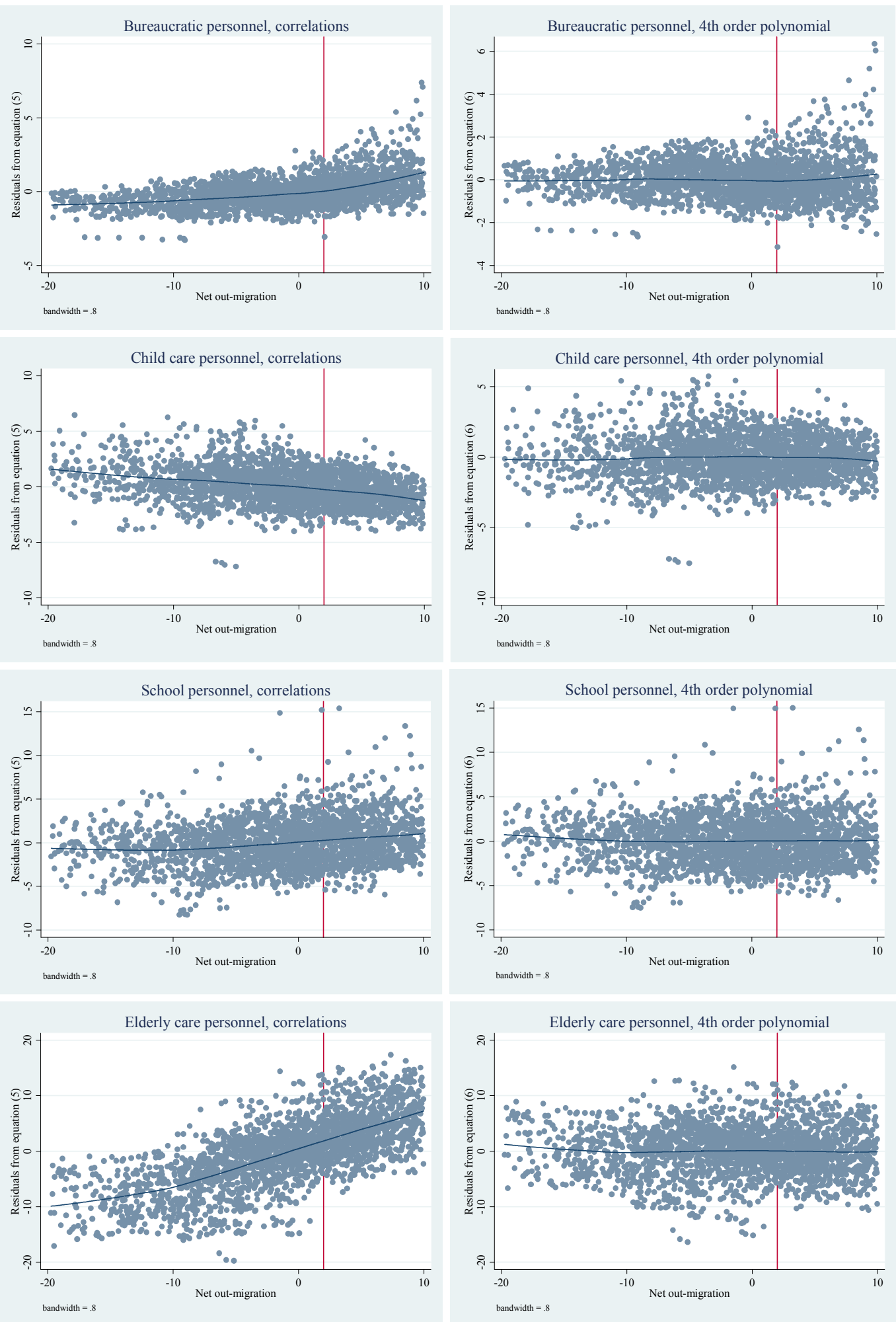


\subsection{Other covariates}

Since we argue that our method estimates a direct causal effect similar to that in an experimental setting, there is, except for efficiency reasons, no need to control for any additional covariates. If, however, the point estimates change when controlling for additional covariates, the plausibility of exogeneity must be questioned. We will therefore check whether the point estimates from the baseline IV regression are sensitive to the inclusion of additional covariates. The idea is that if the point estimates are insensitive to controlling for observables, then they should also be insensitive to the inclusion of unobserved variables hidden in the error term, that is, the omitted variable bias is likely to be quite small. Our choice of control variables are wages for municipal employees, tax base per capita, total population, share of population aged $0-6$, share of population aged $7-15$, share of population aged $80+$, and share of foreign-born citizens, all of which can be suspected to affect municipal personnel.

The second column in Table 4 presents 2SLS estimates of $\alpha_{1}$ from equation (4) when including the additional covariates. ${ }^{20}$ For expositional purposes we only present the estimates from a specification with a $4^{\text {th }}$ order polynomial in the net out-migration rate. The first column reproduces the baseline estimates from Table 3. What one should look for are possible differences between the point estimates in the two columns. Doing that, we see that the results are fairly robust - there is a slight decrease in magnitudes but there is still a substantial effect of around 0.7 for bureaucrats and still no effect on the other types of municipal personnel. These results support the view that the instrument provides an exogenous variation.

\footnotetext{
${ }^{20}$ It should be noted that the first-stage estimates from these regressions are virtually unchanged compared to those from the baseline regressions presented in Table 2 and we do therefore not report them.
} 


\begin{tabular}{lll}
\hline & Baseline estimates & $\begin{array}{l}\text { Estimates when including } \\
\text { additional covariates }\end{array}$ \\
\hline Bureaucrats & $0.837 * * *$ & $0.755^{* * *}$ \\
Personnel in child care & $(0.296)$ & $(0.254)$ \\
& 0.008 & 0.006 \\
Personnel in schools & $(0.243)$ & $(0.224)$ \\
& -0.318 & -0.213 \\
Personnel in elderly care & $(0.285)$ & $(0.238)$ \\
& -0.190 & 0.016 \\
& $(0.274)$ & $(0.178)$ \\
\hline \# of observations & 2,511 & 2,511
\end{tabular}

Notes: The four rows report standardized estimates of $\alpha_{1}$ in the second-stage equation (4) with dependent variable bureaucrats, child care, school, and elderly care personnel, respectively, with additional covariates (in the second column) average wages, tax base per capita, total population, share of population aged $0-6$, share of population aged $7-15$, share of population aged $80+$, and share of foreignborn citizens. Robust standard errors adjusted for within cross-sectional serial correlation in parentheses. $* * *, * *$ and $*$ denotes significance at the 1,5 and 10 percent level. Time dummies and smooth functions with out-migration in $4^{\text {th }}$ order polynomial are included in the estimations.

\subsection{Testing overidentifying restrictions using an additional discontinuity}

The most common way to test for instrument validity is to use some test for overidentifying restrictions (like the Hansen $J$ test). Since the baseline model is exactly identified, this approach is not viable for us. However, in the year 2000 an additional discontinuous component was introduced in the cost equalization where municipalities were compensated also for the change in the number of school-aged children. This compensation was conditioned on the net out-migration rate during the past three years (with a two year lag, $m_{(i, t-2)-(i, t-5)}$ ), which had to be larger than two percent. Municipality $i$ thus received additional out-migration grants in year $t\left(g_{i, t}^{m, s}\right)$ according to the following rule:

$$
g_{i, t}^{m, s}\left\{\begin{array}{l}
>0 \text { if } s_{(i, t-2)-(i, t-5)}<0 \text { and } m_{(i, t-2)-(i, t-5)}>2 \\
=0 \text { otherwise }
\end{array}\right.
$$


where $s_{(i, t)-(i, t-j)}$ is the net change in the number of school-aged children in municipality $i$ between year $t$ and year $t-j .{ }^{21}$ That is, for the shorter time period 2000-04, we have two discontinuous grant rules; the rule in equation (2) and the rule in equation (7). As a third approach to investigate the exogeneity of the instrument, we will make use of the additional grant formula and re-estimate our model with two instruments for the shorter time period. $^{22}$ Thereafter we can conduct the Hansen $J$ test of instrument validity/correct model specification. ${ }^{23}$

For the period 2000-04, the first stage is now given by

$$
\begin{aligned}
g_{i, t}= & \gamma_{0}+\gamma_{1} \Omega^{m}\left(m_{(i, t-2)-(i, t-12)}\right)+\gamma_{2} \Omega^{s}\left(s_{(i, t-2)-(i, t-5}\right)+f\left(\mathbf{m}_{(i, t-2)-(i, t-12)} ; \phi\right)+ \\
& h\left(\mathbf{s}_{(i, t-2)-(i, t-5} ; \theta\right)+\eta_{i, t},
\end{aligned}
$$

where $\Omega^{m}\left(m_{(i, t-2)-(i, t-12)}\right)$ is the grant rule given in equation $(1), \Omega^{s}\left(s_{(i, t-2)-(i, t-5}\right)$ is the grant rule given in equation (7), and $f(\cdot)$ and $h(\cdot)$ are smooth functions of the treatment-determining covariates. The $h$-function plays a similar role as the $f$-function, i e it controls for any direct effects that the change in the number of school-aged children might have on local personnel. Thus, the arguments in $h(\cdot)$ are $2^{\text {nd }}-4^{\text {th }}$ order polynomials in the change in school-aged children. The second-stage counterpart to equation (8) is then given by

$$
y_{i, t}=\alpha_{0}+\alpha_{1} \hat{g}_{i, t}+f\left(\mathbf{m}_{(i, t-2)-(i, t-12)} ; \boldsymbol{\delta}\right)+h\left(\mathbf{s}_{(i, t-2)-(i, t-5} ; \boldsymbol{\lambda}\right)+\varepsilon_{i, t},
$$

where $\hat{g}$ is predicted grants given by the estimation of equation (8).

\footnotetext{
${ }^{21}$ During 2000-01, this compensation was based on changes in the age group 7-15 and in 2002-04 on changes in the age group 7-18. The mean of the school grants variable is 9.7 SEK per capita with a standard deviation of 60.3 (minimum value is -10.2 and maximum value is 752.1). The mean of the net change in the number of school-aged children is 2.65 percent with a standard deviation of 4.08 (minimum value is -10.25 and maximum value is 23.59 ).

${ }^{22}$ As noted in the introduction the identification strategy in this paper is a version of the one in Dahlberg et al. (forthcoming). They did not, however, separate the two discontinuities into two instruments and were thus not able to test any overidentifying restrictions.
} 
Starting with the first-stage estimates, it is clear from the results presented in Table 5 that both instruments are relevant - for any order of polynomial in the treatmentdetermining covariates, both $\gamma_{1}$ and $\gamma_{2}$ are significantly different from zero at the five percent level. Turning to the second-stage estimates, presented in Table 6, it can be noted that according to the Hansen $J$-statistic, we cannot reject the null hypothesis of valid instruments/a correct model specification for any of the outcome variables when using a $3^{\text {rd }}$ or $4^{\text {th }}$ order polynomial. Hence, also the third test indicates that our instrument is exogenous.

It is also interesting to see that we for this shorter time period and with two discontinuous grant rules as excluded instruments get very similar results (both with respect to the point estimates and significance levels) as in the baseline specification. This strengthens our conclusion that marginal increases in grants increase the number of bureaucrats, but not the number of personnel in child care, schooling and elderly care.

Table 5 First-stage estimates when using two discontinuous rules.

\begin{tabular}{lll}
\hline Dependent variable: & Cost-equalizing grants & \\
\hline Excluded instrument: & Migration grants & School grants \\
\hline $2^{\text {nd }}$ order polynomial & $2.648^{* * *}$ & $6.830^{* * *}$ \\
& $(0.783)$ & $(2.596)$ \\
\multirow{2}{*}{$3^{\text {rd }}$ order polynomial } & $3.828^{* *}$ & $5.781^{* *}$ \\
& $(1.549)$ & $(2.536)$ \\
$4^{\text {th }}$ order polynomial & $4.102^{* *}$ & $5.963^{* *}$ \\
& $(1.641)$ & $(2.493)$ \\
\hline \# of observations & 1,395 & \\
\hline
\end{tabular}

Notes: The table presents estimates of $\gamma_{1}$ and $\gamma_{2}$ in the first-stage equation (8). Robust standard errors adjusted for within cross-sectional serial correlation in parentheses. ${ }^{* * *}$ and $* *$ denotes significance at the 1 and 5 percent level. Time dummies and smooth functions with out-migration and change in school-aged children in $2^{\text {nd }}-4^{\text {th }}$ order polynomial are included in the estimations.

\footnotetext{
${ }^{23}$ Worth noting is that the Hansen $J$ statistic really tests whether several distinct instruments result in the same estimate. To rely on the Hansen $J$ as a test for instrument exogeneity one therefore has to assume i) that one of the instrument is exogenous and ii) homogenous treatment effects.
} 
Table 6 2SLS estimates with two discontinuous rules.

\begin{tabular}{lllll}
\hline Dependent variable: & Bureaucrats & $\begin{array}{l}\text { Personnel in } \\
\text { child care }\end{array}$ & $\begin{array}{l}\text { Personnel in } \\
\text { schools }\end{array}$ & $\begin{array}{l}\text { Personnel in } \\
\text { elderly care }\end{array}$ \\
\hline $2^{\text {nd }}$ order polynomial & $0.641^{* * *}$ & -0.236 & -0.282 & -0.199 \\
& $(0.163)$ & $(0.185)$ & $(0.239)$ & $(0.176)$ \\
Hansen J-statistic & 0.163 & 1.191 & 3.580 & 6.691 \\
[p-value] & {$[0.686]$} & {$[0.275]$} & {$[0.059]$} & {$[0.010]$} \\
$3^{\text {rd }}$ order polynomial & $0.773 * * *$ & -0.008 & -0.192 & -0.014 \\
& $(0.242)$ & $(0.225)$ & $(0.283)$ & $(0.190)$ \\
Hansen J-statistic & 0.896 & 0.000 & 1.568 & 1.231 \\
[p-value] & {$[0.344]$} & {$[0.985]$} & {$[0.211\}$} & {$[0.267]$} \\
$4^{\text {th }}$ order polynomial & $0.698 * * *$ & 0.001 & -0.151 & -0.019 \\
& $(0.233)$ & $(0.201)$ & $(0.264)$ & $(0.190)$ \\
Hansen J-statistic & 0.745 & 0.001 & 1.480 & 1.214 \\
[p-value] & {$[0.388]$} & {$[0.975]$} & {$[0.224]$} & {$[0.271]$} \\
\hline \# of observations & 1,395 & 1,395 & 1,395 & 1,395 \\
\hline
\end{tabular}

Notes: The four columns report standardized estimates of $\alpha_{1}$ in the second-stage equation (9) with dependent variable bureaucrats, child care, elderly care and school personnel, respectively. Robust standard errors adjusted for within cross-sectional serial correlation in parentheses. Hansen J-statistic and [p-value] in italics. $* * * * *$, and $*$ denotes significance at the 1,5 , and 10 percent level. Time dummies and smooth functions with out-migration and change in school-aged children in $2^{\text {nd }}-4^{\text {th }}$ order polynomial are included in the estimations.

To sum up the results from the fairly thorough check of instrument validity provided in this section, we think that we can be quite confident in the exogeneity of the instrument and, hence, in the baseline results presented in section 5 .

\section{What type of bureaucrats is employed when grants increase?}

The pool of personnel in the central administration, as we have defined it so far, is fairly broad. It includes everyone from employees in more basic administrative services to high officials and heads of local public authorities. With unique access to register data on all individuals employed by the municipalities we are however able to refine our analysis by studying the lower and upper part of the distribution of influential bureaucrats separately. This will tell us something about what type of bureaucrats that gets hired when the municipality employs more personnel after a marginal increase in grants. 
Once again equation (4) is estimated, with dependent variables now being administrative personnel and high officials respectively, and the resulting $\alpha_{1}$ estimates are shown in Table 7. From there it appears as increases in employment take place among those which one would think are the least powerful in local politics, as opposed to among high officials. With a $4^{\text {th }}$ order polynomial in the smooth function, a one standard deviation increase in grants leads to around one half standard deviation increase in administrative personnel. Or, equivalently, an increase in grants of 100 SEK leads to around 0.013 more full-time equivalents per 1,000 capita, which is close to 1.5 percent of the mean for this personnel category.

Table 7 Effects of grants on different types of bureaucrats. 2SLS estimates.

\section{Dependent variable: $\quad$ Administrative personnel High officials}

\begin{tabular}{lll}
\hline $2^{\text {nd }}$ order polynomial & $0.604 * * *$ & -0.065 \\
& $(0.175)$ & $(0.142)$ \\
$3^{\text {rd }}$ order polynomial & $0.602^{* *}$ & -0.100 \\
& $(0.261)$ & $(0.209)$ \\
$4^{\text {th }}$ order polynomial & $0.478^{* *}$ & -0.001 \\
& $(0.223)$ & $(0.179)$ \\
\hline \# of observations & 2,476 & 2,511
\end{tabular}

Notes: The two columns report standardized estimates of $\alpha_{1}$ in the second-stage equation (4) with dependent variable being administrative personnel and high officials, respectively. Robust standard errors adjusted for within cross-sectional serial correlation in parentheses. $* * *, * *$ and $*$ denotes significance at the 1,5 and 10 percent level. Time dummies and smooth functions with out-migration in $2^{\text {nd }}-4^{\text {th }}$ order polynomial are included in the estimations.

How well does this finding correspond to the idea that bureaucrats use their power over the decision-making process to achieve selfish goals? If such power exists, it is likely that it is the high officials that possess the power, not the administrative personnel. We can think of a couple of possible reasons for why high officials would use their power to employ more administrative personnel instead of more high officials. First, the number of positions for high officials is probably quite restricted - an institution can have only a certain amount of directors. This restricts the scope for new appointments. Second, a large staff of administrators will be able to cover a variety of tasks that would otherwise be assigned to someone further up the ladder. Hence, by employing more administrative 
personnel, the high officials can reduce their own work load. Finally, having a large staff of administrator also increase the number that the higher officials are bosses over, which gives them more power.

\section{Concluding remarks}

Bureaucrats pursuing own selfish goals may cause a discrepancy between what elected representatives intend to do and what is actually being done - a discrepancy that ultimately means that the implemented policy will be different from the one that voters desire. Due to factors such as asymmetric information and difficulties in measuring output, monitoring bureaucratic behavior is very problematic. To find empirical support for the hypothesis that bureaucrats self-interestedly pursue own goals is even more difficult, since the nature of such behavior implies that, if undertaken, they would probably put in effort to avoid people finding out about it. In this paper we have suggested and applied one way of testing this. Making use of a discontinuity in the Swedish grant system we are able to estimate causal effects of intergovernmental grants on personnel in different local government sectors and compare the effects across sectors. The pattern of results is quite clear - the marginal effects of additional grants on bureaucratic employment is significant and large, while there is no significant effect on the number of personnel in child care, schools, or elderly care. This is a pattern that we interpret as indicating that bureaucrats have an independent say in the decisions on what to do with additional grants, and that they use this power to achieve selfish goals. In addition, the variety of ways in which the validity of the instrument is examined and verified indicates that the discontinuous grant indeed is a good instrument, so we can be quite confident that the estimated results represent causal effects and not only correlations.

It should be noted that an alternative interpretation of the presented pattern of grants effects on personnel in different sectors is that it is the politicians, not the bureaucrats themselves, who want to have a larger bureau to assist them in their work. We cannot separate between these two explanations. However, some indication that it is in fact 
bureaucrats rather than politicians that desire a large administrative sector is survey evidence in SKL (2005); as mentioned in the paper, more than half of the local politicians that took part in a survey investigation in 2005 felt that the role as a politician simply was to approve proposals made by bureaucrats.

Also, we cannot exclude that bureaucrats choose to increase the administrative staff because they think that this actually is the best use of the extra grants from the voters' perspective. It is, however, hard to believe that voters would prefer more bureaucrats rather than, e g, more teachers or a larger nursing staff. 


\section{References}

Alesina, A and G Tabellini (2007), "Bureaucrats or Politicians? Part I: A Single Policy Task", The American Economic Review vol 97, pp 169-179.

Angrist, J D and V Lavy (1999), "Using Maimonides' Rule to Estimate the Effect of Class Size on Scholastic Achievement", The Quarterly Journal of Economics vol 114, pp 533-575.

Bergström, P, M Dahlberg and E Mörk (2004), "The Effect of Grants and Wages on Municipal Labour Demand", Labour Economics vol 11, pp 315-334.

Besley, T and A Case (2000), "Unnatural Experiments? Estimating the Incidence of Endogenous Policies“, Economic Journal vol 110, pp F672-F694.

Brueckner, J K and KM O’Brien (1989), “Modeling Government Behaviour in Collective Bargaining: A Test for Self-interested Bureaucrats", Public Choice vol 63, pp 15-41.

Card, D and E Moretti (2007), "Does Voting Technology Affect Election Outcomes? Touch-screen Voting and the 2004 Presidential Election", The Review of Economics and Statistics vol 89, pp 660-673.

Dahlberg, M and E Mörk (2006), "Public Employment and the Double Role of Bureaucrats", Public Choice vol 126, pp 387-404.

Dahlberg, M, E Mörk, J Rattsø and H Ågren (forthcoming), “Using a Discontinuous Grant Rule to Identify the Effect of Grants on Local Taxes and Spending”, Journal of Public Economics. 
Dewatripont, M, I Jewitt and J Tirole (1999), “The Economics of Career Concerns, Part II: Application to Missions and Accountability of Government Agencies", Review of Economic Studies vol 66, pp 199-217.

Downs, A (1957), An Economic Theory of Democracy, Harper and Row, New York.

Duggan, M and S D Levitt (2002), “Winning isn't Everything: Corruption in Sumo Wrestling”, The American Economic Review vol 92, pp 1594-1605.

Filimon, R, T Romer and H Rosenthal (1982), “Asymmetric Information and Agenda Control", Journal of Public Economics vol 17, pp 51-70.

Gordon, N (2004), "Do Federal Grants Boost School Spending? Evidence from Title I", Journal of Public Economics vol 88, pp 1771-1792.

Guryan, J (2003), “Does Money Matter? Estimates from Education Finance Reform in Massachusetts“, mimeo, University of Chicago. An earlier version of the paper was published as NBER Working Paper No 8269.

Hahn, J, P Todd and W Van der Klaauw (2001), "Identification and Estimation of Treatment Effects with a Regression-discontinuity Design”, Econometrica vol 69, pp 201-209.

Jacob, B A and S D Levitt (2003), "Rotten Apples: An Investigation of the Prevalence and Predictors of Teacher Cheating", The Quarterly Journal of Economics vol 118, pp $843-877$.

Kalseth, J and J Rattsø (1997), "Political Control of Administrative Spending: The Case of Local Governments in Norway", Economics and Politics vol 10, pp 63-83. 
Knight, B 2002), "Endogenous Federal Grants and Crowd-out of State Government Spending: Theory and Evidence from the Federal Highway Aid Program", The American Economic Review vol 92, pp 71-92.

Lee, D S (2008), "Randomized Experiments from Non-random Selection in U.S. House Elections", Journal of Econometrics vol 142, pp 675-697.

Lipsky, M (1980) Street-level Bureaucracy: Dilemmas of the Individual in Public Services, Russell Sage Foundation, New York.

McGuire, T G (1981), "Budget-maximizing Government Agencies: An Empirical Test", Public Choice vol 36, pp 313-322.

Moene, K (1986), “Types of Bureaucratic Interaction”, Journal of Public Economics vol 29, pp 333-345.

Montin, S (2002), Moderna kommuner, $1^{\text {st }}$ edition, Liber, Malmö. (In Swedish)

Mueller, D C (1989), Public Choice II, Cambridge University Press, Cambridge.

Niskanen, W (1971), Bureaucracy and Representative Government, Aldine-Atherton, Chicago.

Ott, M (1980), "Bureaucracy, Monopoly, and the Demand for Municipal Services", Journal of Urban Economics vol 8, pp 362-282.

Peters, G B (1995), The Politics of Bureaucracy, $4^{\text {th }}$ Edition, White Plains, New York.

Romer, T and H Rosenthal (1979), "Bureaucrats Versus Voters: On the Political Economy of Resource Allocation by Direct Democracy", Quarterly Journal of Economics vol 93, pp 563-587. 
Romer, T and H Rosenthal (1982), "Median Voters or Budget Maximizers: Evidence from School Expenditure Referenda", Economic Inquiry vol 20, pp 556-578.

Romer, T, H Rosenthal and V G Munley (1992), "Economic Incentives and Political Institutions: Spending and Voting in School Budget Referenda", Journal of Public Economics vol 49, pp 1-33.

Shapiro, P and J Sonstelie (1982), “Did Proposition 13 Slay Leviathan?”, The American Economic Review vol 72, pp 184-190.

SKL (2005), Makten och möjligheten i kommunpolitiken. En enkätstudie om förtroendevalda i 17 kommuner, Stockholm. (In Swedish)

The Instrument of Government, Chapter 1 Art 1, SFS no: 1974:152.

Tullock, G (1965), The Politics of Bureaucracy, Public Affairs Press, Washington D.C.

Wilson, J Q (1989), Bureaucracy: What Government Agencies Do and Why They Do It, Basic Books, New York. 
WORKING PAPERS*

Editor: Nils Gottfries

2007:14 David Kjellberg and Erik Post, A Critical Look at Measures of Macroeconomic Uncertainty. 27pp.

2007:15 Mikael Carlsson and Andreas Westermark, Optimal Monetary Policy under Downward Nominal Wage Rigidity. 52pp.

2007:16 Robin Douhan and Anders Nordberg, Is the elephant stepping on its trunk? The problem of India's unbalanced growth. 33pp.

2007:17 Annika Alexius and Bertil Holmlund, Monetary Policy and Swedish Unemployment Fluctuations. 27pp.

2007:18 Meredith Beechey and Pär Österholm, The Rise and Fall of U.S. Inflation Persistence. 23pp.

2007:19 Henry Ohlsson and Donald Storrie, Long term effects of public policy for displaced workers in Sweden - shipyard workers in the West and miners in the North. 26pp.

2007:20 Niklas Bengtsson, How responsive is body weight to transitory income changes? Evidence from rural Tanzania. 38pp.

2007:21 Karin Edmark, Strategic Competition in Swedish Local Spending on Childcare, Schooling and Care for the Elderly. 38pp.

2007:22 Fredrik Johansson, How to Adjust for Nonignorable Nonresponse: Calibration, Heckit or FIML? 25pp.

2007:23 Henry Ohlsson, The legacy of the Swedish gift and inheritance tax, 18842004. 25pp.

2007:24 Ranjula Bali Swain and Fan Yang Wallentin, DOES MICROFINANCE EMPOWER WOMEN? Evidence from Self Help Groups in India. 26pp.

2007:25 Bertil Holmlund and Martin Söderström, Estimating Income Responses to Tax Changes: A Dynamic Panel Data Approach. 34pp.

2007:26 N. Anders Klevmarken, Simulating the future of the Swedish baby-boom generations. 60pp.

2007:27 Olof Åslund and Oskar Nordström Skans, How to Measure Segregation Conditional on the Distribution of Covariates. 17pp.

2007:28 Che-Yuan Liang, Is There an Incumbency Advantage or a Cost of Ruling in Proportional Election Systems? 20pp.

\footnotetext{
* A list of papers in this series from earlier years will be sent on request by the department.
} 
2007:29 Stefan Eriksson and Jonas Lagerström, Detecting discrimination in the hiring process: Evidence from an Internet-based search channel. 31pp.

2007:30 Helge Berger and Pär Österholm, Does Money Growth Granger-Cause Inflation in the Euro Area? Evidence from Out-of-Sample Forecasts Using Bayesian VARs. 32pp.

2007:31 Ranjula Bali Swain and Maria Floro, Effect of Microfinance on Vulnerability, Poverty and Risk in Low Income Households. 35pp.

2008:1 Mikael Carlsson, Johan Lyhagen and Pär Österholm, Testing for Purchasing Power Parity in Cointegrated Panels. 20pp.

2008:2 Che-Yuan Liang, Collective Lobbying in Politics: Theory and Empirical Evidence from Sweden. 37pp.

2008:3 Spencer Dale, Athanasios Orphanides and Pär Österholm, Imperfect Central Bank Communication: Information versus Distraction. 33pp.

2008:4 Matz Dahlberg and Eva Mörk, Is there an election cycle in public employment? Separating time effects from election year effects. 29pp.

2008:5 Ranjula Bali Swain and Adel Varghese, Does Self Help Group Participation Lead to Asset Creation. 25pp.

2008:6 Niklas Bengtsson, Do Protestant Aid Organizations Aid Protestants Only? 28pp.

2008:7 Mikael Elinder, Henrik Jordahl and Panu Poutvaara, Selfish and Prospective Theory and Evidence of Pocketbook Voting. 31pp.

2008:8 Erik Glans, The effect of changes in the replacement rate on partial retirement in Sweden. 30pp.

2008:9 Erik Glans, Retirement patterns during the Swedish pension reform. 44pp.

2008:10 Stefan Eriksson and Jonas Lageström, The Labor Market Consequences of Gender Differences in Job Search. 16pp.

2008:11 Ranjula Bali Swain and Fan Yang Wallentin, Economic or Non-Economic Factors - What Empowers Women?. 34pp.

2008:12 Matz Dahlberg, Heléne Lundqvist and Eva Mörk, Intergovernmental Grants and Bureaucratic Power. 34pp.

See also working papers published by the Office of Labour Market Policy Evaluation http://www.ifau.se/ 